\title{
Upaya Peningkatan Hasil Belajar IPA Melalui Metode Demonstrasi
}

\author{
Inti Lestarai \\ UPK Kecamatan Lumbir \\ Butulan, Lumbir, Kec. Lumbir, Kabupaten Banyumas, Jawa Tengah \\ Email: bdmartono7@gmail.com
}

\begin{abstract}
Abstrak
Tujuan Penelitian Tindakan Kelas ini adalah meningkatkan hasil belajar siswa kelas 1 SD Negeri 2 Karanggayam Kidul Kec Purwojati, melalui penerapan metode demonstrasi (percobaan) sehingga pembelajaran IPA tentang materi benda yang dapat diubah bentuknya tercapai.Desain penelitian dilaksanakan melalui dua siklus, mulai dari perencanaan, pelaksanaan, tindakan, observasi, refleksi dan dilanjutkan dengan perencanaan siklus berikutnya. Hasil perbaikan tindakan kelas ini adalah rata-rata nilai hasil belajar siswa mengalami peningkatan dari kondisi awal 60,1 dapat meningkat menjadi 71,5 pada siklus I. Sedangkan pada siklus II menjadi 75,6 . Ditinjau dari ketuntasan pada studi awal 16 siswa tuntas, siklus I 26 siswa tuntas dan siklus II 33 siswa tuntas dari 34 siswa dengan nilai ketuntasan 70 keatas.Berdasarkan temuan hasil penelitian ini dapat disimpulkan bahwa penerapan metode demonstrasi (percobaan) pada pembelajaran IPA tentang materi benda yang dapat diubah bentuknya tercapai dapat meningkatkan hasil belajar siswa kelas 1 SD Negeri 1 Karangtalun Kidul
\end{abstract}

Kata Kunci: metode demonstrasi, PTK IPA di SD

\begin{abstract}
The purpose of this Classroom Action Research is to improve student learning outcomes in grade 1 SD Negeri 2 Karanggayam Kidul Kec Purwojati, through the application of demonstration methods (experiments) so that natural science learning about material objects that can be changed in shape is achieved. The research design is carried out through two cycles, starting from planning, implementation, action, observation, reflection and proceed with planning the next cycle. The results of this class action improvement is the average value of student learning outcomes have increased from the initial condition of 60.1 can increase to 71.5 in cycle I. While in cycle II to be 75.6. In terms of completeness in the initial study 16 students completed, cycle I 26 students completed and cycle II 33 students completed from 34 students with completeness values of 70 and above. Based on the findings of the results of this study it can be concluded that the application of the demonstration method (experiment) in natural science learning about material objects which can be changed in shape can improve student learning outcomes in grade 1 SD Negeri 1 Karangtalun Kidul
\end{abstract}

Keywords: demonstration method, PTK IPA in elementary school

\section{PENDAHULUAN}

Proses pembelajaran akan berjalan dengan baik apabila guru memiliki kemampuan dalam menciptakan suasana belajar siswa menyenangkan, belajar hakekatnya merupakan suatu proses yang akitf melibatkan panca indra, fisik dan psikis siswa. Seorang guru juga 
perlu memperhatikan kemampuan diri saat memilih metode pembelajaran. Berdasarkan pengamatan peneliti dan data yang ada pada hasil ulangan harian. Pembelajaran Ilmu Pengetahuan Alam (IPA) dengan materi pokok Benda yang dapat diubah bentuknya hasilnya rendah, belum memenuhi standar ketuntasan minimal yang telah ditentukan yakni 70 hal tersebut dapat dilihat pada hasil ulangan harian pada siswa kelas I SD Negeri 1 Karanggayam, Kecamatan Lumbir pada studi awal. Dengan dibuktikan oleh hasil ulangan pada studi awal yang dikerjakan siswa kelas I dengan materi pokok pokok Benda yang dapat diubah bentuknya dari 34 siswa (47 \%) yang memenuhi Kriteria Ketuntasan Minimal (KKM) dengan nilai KKMnya 70. Dengan demikian ada 18 siswa yang belum berhasil mencapai nilai ketuntasan. Dilihat dari sisi guru sebagai pendidik dan pengajar belum sepenuhnya memahami karakteristik siswa dan latar belakang siswa kelas I belum memahami konsep yang disajikan secara abstrak yang terkait dengan penggolongan makhluk hidup, sedangkan guru seringkali mengajar lebih dominan menggunakan metode ceramah yang relatif abstrak, jarang menggunakan metode penelitian (inquiry) yang dapat menyederhanakan konsep yang sulit atau sukar.

Metode demonstrasi adalah metode yang menunjukkan suatu proses praktik atau percobaan dalam suatu permasalahan untuk didapatkan suatu kesimpulan dan mencapai suatu tujuan. Metode demonstrasi ini seringkali digunakan dalam sebuah proses pembelajaran namun kebanyakan belum maksimal karena waktu pembelajaran yang sedikit. Peragaan demonstrasi digunakan oleh guru ketika guru akan menjelaskan suatu proses cara kerja sebuah alat peraga di hadapan siswa, sehingga membangkitkan sikap antusiasme siswa dalam sebuah pembelajaran dan memotivasi rasa ingin tahu yang dalam untuk melakukan percobaan yang telah dicontohkan oleh gurunya. Prosedur metode demonstrasi yang harus dilakukan dalam pembelajaran adalah (a) Mempersiapkan alat bantu yang akan digunakan dalam pembelajaran; (b) Memberikan penjelasan tentang topik yang akan didemonstrasikan; (c) Pelaksanaan demonstrsi bersamaan dengan perhatian dan peniruan dari siswa; (d) Penguatan (diskusi, tanya jawab, dan atau latihan) terhadap hasil demonstrasi; dan (e) Kesimpulan. Penerapan model pembelajaran demonstrasi dapat dilaksanakan pada mata pelajaran IPA. Hakekat Sains dan Pembelajaran Sains di Sekolah Dasar Ilmu pengetahuan alam (IPA) atau Sains dalam arti sempit telah dijelaskan diatas merupakan disiplin ilmu yang terdiri dari physical sciences (ilmu fisik) dan life sciences (ilmu biologi). Yang termasuk physical sciences adalah ilmu-ilmu astronomi, kimia, geologi, mineralogi, meteorologi, dan fisika, sedangkan life science meliputi anatomi, fisiologi, zoologi, citologi, embriologi, mikrobiologi. IPA (Sains) berupaya 
membangkitkan minat manusia agar mau meningkatkan kecerdasan dan pemahamannya tentang alam seisinya yang penuh dengan rahasia yang tak habis-habisnya. Dengan tersingkapnya tabir rahasia alam itu satu persatu, serta mengalirnya informasi yang dihasilkannya, jangkauan Sains semakin luas dan lahirlah sifat terapannya, yaitu teknologi adalah lebar. Namun dari waktu jarak tersebut semakin lama semakin sempit, sehingga semboyan "Sains hari ini adalah teknologi hari esok" merupakan semboyan yang berkalikali dibuktikan oleh sejarah. Dalam kegiatan pembelajaran IPA, salah satu tujuan utamanya adalah meningkatkan hasil belajar siswa. Hasil belajar merupakan hal yang dapat dipandang dari dua sisi yaitu sisi siswa dan dari sisi guru. Dari sisi siswa, hasil belajar merupakan tingkat perkembangan mental yang lebih baik bila dibandingkan pada saat sebelum belajar. Tingkat perkembangan mental tersebut terwujud pada jenis-jenis ranah kognitif, afektif, dan psikomotor (Slametto, 2003:16). Hasil belajar adalah bila seseorang telah belajar akan terjadi perubahan tingkah laku pada orang tersebut, misalnya dari tidak tahu menjadi tahu, dan dari tidak mengerti menjadi mengerti (Hamalik, 2006:30). Teori Taksonomi Bloom hasil belajar dalam rangka studi dicapai melalui tiga kategori ranah antara lain kognitif, afektif, psikomotor.

\section{METODE PENELITIAN}

Subjek Penelitian yang dilakukan meliputi lokasi, waktu dan mata pelajaran, kelas dan karakteristik siswa. Perbaikan Pembelajaran Ilmu Pengetahuan Alam (IPA) materi pokok mengenal benda yang dapat diubah bentuknya dengan menggunakan metode demonstrasi (percobaan). Adapun tempat penelitian dilaksanakan pada SD Negeri 1 Karangtalun Kidul UPK Purwojati. Kelas yang dijadikan objek penelitian adalah siswa kelas I tahun ajaran 2015/2016. Penelitian tindakan kelas di laksanakan dalam wujud proses pengkajian yang berdaur terdiri dari 4 tahapan yakni perencanaan, pelaksanaan, tindakan, observasi dan refleksi. Dalam penelitian tindakan ini peneliti menggunakan desain penelitian kelas dengan 2 siklus yaitu siklus I dan Siklus II. Siklus pertama bertujuan untuk mengetahui kemampuan belajar IPA materi pokok mengenal benda yang dapat diubah bentuknya, hasil siklus digunakan sebagai refleksi untuk melaksanakan siklus II. Hasil dari proses tindakan pada siklus II bertujuan untuk mengetahui peningkatan hasil belajar setelah dilakukan perbaikan dalam kegiatan belajar berdasarkan refleksi siklus I. Dalam Penelitian Tindakan Kelas ini pengumpulan data yang dilakukan dengan menggunakan: 
a. Tes : sebagai alat mengumpulkan data hasil belajar siswa.

b. Lembar observasi siswa : untuk mengumpulkan data tentang persepsi dan opini siswa terhadap proses pembelajaran.

c. Lembar observasi guru : untuk mengumpulkan data tentang kesiapan peneliti dalam kegiatan belajar mengajar (KBM).

\section{HASIL DAN PEMBAHASAN}

\section{Deskripsi Siklus I}

Dari hasil pengamatan pembelajaran siklus I dapat dilihat adanya peningkatan prestasi belajar siswa yang memenuhi KKM sebanyak 8 siswa ( $44,44 \%$ ) dari yang tadinya 6 siswa (33,33\% ) menjadi 14 siswa (77,77\%). Adapun minat belajar siswa kelas I SD Negeri 1 Karangtalun Kidul pada siklus I berada pada skala cukup dengan rata-rata aktivitas belajar siswa sebesar $88,88 \%$ sedangkan jumlah siswa yang mencapai skala kuat dan sangat kuat baru ada 4 siswa $(22,22 \%)$ dari jumlah seluruh siswa. Secara umum berdasarkan data aktivitas belajar siswa pada siklus I masih belum memuaskan, karena pada siklus I belum memenuhi dua indikator kriteria keberhasilan, sehingga akan dilaksanakan perbaikan pembelajaran kembali pada siklus II.

\section{Deskripsi Siklus II}

Dari hasil pengamatan pembelajaran siklus II dapat dilihat adanya peningkatan prestasi belajar siswa yang memenuhi KKM sebanyak 16 siswa ( $88,88 \%$ ) dari yang tadinya 14 siswa $(77,77 \%)$. Adapun minat belajar siswa kelas I SD Negeri 1 Karangtalun Kidul pada siklus II berada pada skala kuat dengan rata-rata aktivitas belajar siswa sebesar $80 \%$ sedangkan jumlah siswa yang mencapai skala kuat dan sangat kuat mencapai 16 siswa ( $80 \%$ ) dari jumlah siswa. Secara umum berdasarkan data aktivitas belajar siswa pada siklus II dikatakan sudah berhasil, karena telah memenuhi dua kriteria indikator keberhasilan, yaitu:

1. Jumlah siswa kelas I yang mencapai KKM telah mencapai $80 \%$

2. Jumlah siswa kelas I yang minat belajarnya mencapai skala kuat pada interprestasi skor mencapai $80 \%$.

Hasil pembelajaran dengan Penerapan metode demonstrasi sebagai media pembelajaran lebih bermakna bagi siswa. Ditambah dengan pembelajaran yang lebih bervariasi dengan menggunakan metode demonstrasi (dengan menggunakan gambar sumber energi dan benda-benda konkret agar siswa lebih mengerti dan lebih memahaminya, metode diskusi dan eksperimen (percobaan). Siswa bekerja dan mengalami 
secara langsung menyebabkan siswa terangsang dan berperan aktif dalam pembelajaran.Variabel lain yang memberi dukungan dalam proses mencapai prestasi belajar dan minat belajar siswa mencakup dua komponen yaitu proses pengaturan jumlah kelompok kerja yang lebih kecil (4 siswa tiap kelompok) dan sumber bahan dan media yang memadai.

Dalam hal ini, media yang memadai didukung dengan pengadaan benda-benda konkret sebagai alat bantu belajar sebagaimana pendapat Jean Piaget dalam Baharudin Esa (2006 : 47) bahwa anak-anak usia SD berusia 7-12 tahun berada pada tahap operasional konkret, sehingga proses belajar pun diawali dari hal-hal atau benda-benda konkret. Sehubungan dengan alat bantu belajar konkret, peneliti membuktikan pendapat Rusna Ristasa (2006 : 42) bahwa salah satu manfaat alat bantu belajar adalah meletakkan dasar berpikir konkret, mengurangi verbalisme serta memperbesar minat dan perhatian terhadap materi pembelajaran. Dalam upaya perbaikan yang dilandasi pendapat pakar pendidikan tersebut keberhasilan ketuntasan belajar siswa dan keaktifan siswa mencapai 77,77\%. Dengan penerapan Penerapan metode demonstrasi sebagai media pembelajaran memberikan hasil yang signifikan lagi setelah adanya penambahan upaya perbaikan yang maksimal. Upaya tersebut yaitu dengan memperbanyak tanya jawab untuk pendalaman materi dan guru memperbanyak penekanan pada materi-materi penting. Hal ini senada dengan pendapat Varmon A. Magnesen (dalam Cipto Waluyo, 2003 : 13) siswa belajar 10 $\%$ dari apa yang mereka baca, $20 \%$ dari apa yang mereka lihat, $30 \%$ dari apa yang mereka dengar, $50 \%$ dari apa yang mereka lihat dan dengar, $70 \%$ dari apa yang mereka katakan, $90 \%$ dari apa yang mereka katakan dan lakukan.

Pada proses pendalaman materi, siswa dirangsang dengan pertanyaan seputar percobaan dan hasilnya, dan siswa jugalah yang menilai jawaban tersebut. Guru hanya memfasilitasi atau sebagai pelurus jawaban siswa, sehingga terjadilah komunikasi multi arah dan mereka saling berebut untuk menjawab. Jadi berdasarkan landasan teori dan hipotesis dalam penelitian ini, terbukti dengan menerapkan model pembelajaran berbasis masalah dapat direspon positif oleh siswa. Respon positif tersebut berimbas pada ketuntasan prestasi belajar siswa dan minat belajar siswa selama proses pembelajaran.

\section{KESIMPULAN}

Penerapan metode demonstrasi pada setiap siklus dapat meningkatkan hasil belajar. Hal ini dapat diketahui bahwa pada siklus I rata-rata nilai subjek penelitian adalah 7,2 maka diakhir siklus II telah berhasil meningkatkan hasil belajar siswa yaitu 75 pada 
mata pelajaran IPA materi pokok benda yang dapat diubah bentuknya bagi kelas I SD Negeri 1 Karangtalun Kidul pada tahun ajaran 2015/2016.

\section{SARAN}

Perlu dilakukan penelitian tindakan kelas dengan menerapkan metode demonstrasi diberbagai materi pelajaran

\section{DAFTAR PUSTAKA}

Anitah Sri W. dkk. 2008. Strategi Pembelajaran SD. Jakarta: Universitas Terbuka.

Diknas, 2000. Penggunaan Alat Peraga. Bandung: CV. Tidar Bandung. ,2005. Pedoman Pembelajaran Kelas Awal Sekolah Dasar. Jakarta: Depdiknas. , 2007. Metode Silabus Tematik Kelas I. Jakarta. Depdiknas.

Purwanto, M. Ngalim. 1992. Psikologi Pendidikan. Bandung: PT. Remaja Rosdakarya.

Winataputra, Udin S, dkk 2006. Strategi Belajar Mengajar. Jakarta: Universitas Terbuka. , 2007. Materi dan Pembelajaran IPA SD. Jakarta: Universitas Terbuka. 2007. Teori Belajar dan Pembelajaran. Jakarta: Universitas Terbuka. 